\title{
SOME PERCEPTIONS OF MENTAL DISORDER IN PRE-PETRINE RUSSIA
}

\author{
by
}

\author{
HORACE W. DEWEY*
}

Anyone seeking information on types of mental problems and their care in pre-Petrine Russia will encounter two obstacles: first, the paucity of sources (particularly from the tenth to the fifteenth centuries), and second, the undeveloped state of psychiatric medicine throughout the medieval world. Disagreements over the diagnosis and treatment of mental illness persist even today, of course. Nonetheless, surviving sources can tell us something about how the Russians perceived-and attempted to deal with-certain mental disorders in the centuries before Peter the Great. In this paper I shall consider several major groups or categories of afflictions, including unynie (a term meaning "depression" or "melancholy"), mental problems attributed to alcoholism (perceived both as a sin and an affliction of the mind), and various other types of irrational behaviour. It should be pointed out that Russians sometimes displayed a reluctance to recognize mental disorder where modern researchers would identify it (e.g., iurodstvo or "divine folly"); on the other hand, Russians occasionally saw "madness" where contemporary medicine might not (e.g. religious or political dissent). Since most of our early sources are clerical, one might suspect that demonology played an important role, but how important?

Gregory Zilboorg has recently come under fire for contending that demonological theories of mental illness prevailed in Western Europe during the Middle Ages and Renaissance. In England, at least, surviving records show that the Crown took jurisdiction of "legal incompetency" cases; there, mental illness was generally attributed to "natural, even psychological" origins rather than to supernatural, demonic causes. ${ }^{1}$

In Russia, however, the view seems indeed to have prevailed that madness was caused by the devil, demons, and unclean spirits. ${ }^{2}$ A corollary of this notion held that mental illness could be healed, with God's help, by saints and even ordinary monks and priests. ${ }^{3}$ So central was the devil's role that common terms for "mad" and "madness" (beshenyi, beshenstvo, besnovatyi, besnovanie) were coined from the word "devil" or "demon" (bes). ${ }^{4}$ To cure a violently-deranged person, the evil spirit had to be induced

\footnotetext{
* Horace W. Dewey, JD, PhD, Professor of Slavic Languages and Literatures and Russian History, University of Michigan, Ann Arbor, MI 48109, USA.

${ }^{1}$ R. Neugebauer, 'Medieval and early modern theories of mental illness', Archs gen. Psychol., 1979, 36: 477-483.

${ }^{2}$ F. Riazanovskii, Demonologiia v drevnerusskoi literature, Moscow, 1915, p. 61.

${ }^{3}$ Ibid., pp. 33-34. A number of specific cases will be discussed throughout this article.

${ }^{4}$ Akademiia nauk SSSR, Institut russkogo iazyka, Slovar' russkogo iazyka XI-XVII vv., 10 vols. to date, vol. 1, Moscow, AN SSSR, pp. 153-156, 183. These terms were generally (but not exclusively) used with reference to violent types of madness.
} 
to leave him through the intercession of a saint, or "cast out" or exorcised from him. ${ }^{5}$ However, Russians did not place all their hopes in exorcism. Nor did clergymen believe that all mental patients could be cured at all, by whatever means. To make matters more complicated, clergymen themselves might fall prey to mental disorders. When that happened, the clergymen might be expected to take the initiative in treating themselves. A case in point was unynie, a term best rendered by the modern word "depression", or the more traditional one "melancholia". 6 Fully described, given a specific name, and treated in a prescribed manner (at least where clergymen were concerned), unynie was obviously widespread in Russia. Byzantine and Russian church fathers worried particularly about the effect of melancholia on monks in monasteries. Hermits in the wilderness also suffered from fits of melancholy or despondency. Occasionally grief (pechal'), with tears, might "renew the soul", but chronic melancholy was another matter. ${ }^{7}$ The Byzantine fathers cautioned that such depression exhausted the soul and lessened its ability to resist temptation. The victim was beset by sloth; he succumbed to a negative attitude, to despair. ${ }^{8}$ Nil Sorskii (1433-1508) warned that once the condition took hold, the soul faced a great task or feat (podvig). The spirit of melancholy (dukh unyniia) was fierce and cruel. The struggle with this spirit was especially difficult for "those who live in silence". Nil described the "terrible waves of depression" which caused the victim to lose hope of recovering. The victim feared that his condition would deteriorate further and, worse still, that God would abandon him. He was assailed by doubt and despair. Would God deprive him of His mercy and deny him forgiveness for his sins? Would he be condemned to eternal torment? ${ }^{9}$

George Fedotov and others have labelled this condition acidie (acedia, Gr. akedia) - a "peculiarly monastic state of spiritual depression, loss of energy and despair" which was one of eight "sins" or "temptations" (pomysly). Fedotov went on to declare that acidie "does not find its place in the Western scheme of sins", ${ }^{10}$ but Basil Clarke reminds us that acedia was an antique concept occurring in Hippocrates, Cicero, and Aretaeus. In Western Europe, the term was later used "for depressions... of novices in monasteries and nunneries against unnatural constraint". Acedia essentially referred to "the utter collapse of the personality and a basic withdrawal" or "mindless apathy". Not surprisingly, it was associated with "the mortal sin of sloth"."

\footnotetext{
${ }^{5}$ The Russian translation of "exorcism" is izgnanie dúkhov or izgnanie nechistoi sily ("driving out of spirits" or "driving out of unclean force"); V. Miuller (compiler), Anglo-russkii slovar', Moscow, 1961, p. 356; and I Gal'perin, (compiler) Bol'shoi anglo-russkii slovar', Moscow, 1972, p. 472. In "intercession", the clergyman and saint intercede with God on behalf of the afflicted person, whereupon God causes the evil spirit to leave. In any event, both in the Catholic West and the Orthodox East, the clergymen were following the lead of Christ and His disciples in "casting out" demons; see, for example, Matthew 5:24, 9:32 and 10:1.

${ }^{6} \mathrm{C}$. Park and L. Shapiro, You are not alone. Understanding and dealing with mental illness, Boston, Little, 1976, pp. 20-26, 44. Cf. S. Jackson, 'Unusual mental states in medieval Europe. I. Medical syndromes of mental disorder: 400-1100 A.D.', J. Hist. Med. 1972, 3: 268, 274-279.

${ }^{7}$ So taught Nil of Sinai, quoted in Khristianskaia Zhizn' po dobrotoliubiiu, Harbin, 1930, p. 127.

8 Ibid., pp. 126-128 (quoting other Byzantine church fathers).

${ }^{9}$ Zhitie $i$ tvoreniia prepodobnogo i bogonosnogo ottsa nashego Nila Sorskogo, Montreal, 1958, pp. 47-50: G. P. Fedotov (editor), A treasury of Russian spirituality, New York. Harper \& Row, 1965, pp. 116-119.

${ }^{10}$ G. P. Fedotov, The Russian religious mind, 2 vols., vol. 2, Cambridge, Mass., Harvard University Press, 1966, pp. 275-276.

II B. Clarke, Mental disorder in earlier Britain. Exploratory studies, Cardiff, University of Wales Press. 1975, pp. 116, 186. The West's John Cassian listed eight deadly sins, which included dejection (tristitia) and
} 
Modern aetiologies and therapies for depression (e.g. with ultraviolet light) ${ }^{12}$ were, of course, unknown in Old Russia. In their place, we find other explanations and recommendations.

First, the "aetiology". It was simple and unequivocal: melancholia was an affliction concocted by the devil to "deprive the soul of trust in God". As for treatment, a series of antidotes existed. One-the principal antidote-was prayer; several Byzantine prayers were specifically directed against melancholy. The victim of unynie was also encouraged to read and to work with his hands. If need be, he could "cry out at the top of his lungs" while praying. He could also force himself "to think of some object, divine or human", to take his mind off himself or to divert his attention from dark thoughts engendered by his depression. In extreme cases, the victim might receive counselling, as it were, by visiting an "experienced and edifying person". Such visits could bring relief, but must not be spent in idle chatter. Indeed, some Holy Fathers recommended that the patient should stay in his cell, alone and silent. ${ }^{13}$ Others held the members of the monastery (or convent) collectively responsible for tending to the spiritual health of their brothers or sisters. ${ }^{14}$

The above-outlined procedures were clearly addressed to monks. Nil was speaking to members of the clergy, and he seems to have been particularly concerned about them because melancholy could diminish their effectiveness in the struggle against the devil. What treatment, then, was offered to lay persons suffering from crippling attacks of depression? We cannot say, but we doubt that victims of melancholy underwent the ritual of "exorcism", which seems to have been reserved for patients with more violent (or flamboyant) symptoms.

A second category of mental disorders in pre-Petrine Russia related to drunkenness and alcoholism. Drinking to excess was an affliction attributed to the devil and a problem which had become "the greatest national sin". ${ }^{15}$ The compilers of the Stoglav, a collection of decrees issued by the Church Council of 1551, described drunkenness as a tragic flaw in the national character. Elsewhere in the Orthodox world, especially in centres like Mount Athos, everyone drank, but never to excess. In Russia, by contrast, alcoholism was rampant among the clergy. The code portrayed widespread drunkenness in the monasteries; in all of them one could observe intoxicated monks and abbots. In the towns, parish priests drank themselves senseless; drunken priests quarrelled, using "improper language", and brawled in church. ${ }^{16}$

\footnotetext{
sloth (accedia); Gregory the Great listed seven deadly sins, including dejection, but not sloth; J. T. McNeill, 'Seven deadly sins', in V. Ferm (editor), An encyclopedia of religion, New York, 1945, p. 705.

${ }^{12}$ A. Lewy, 'Effects of light on human melatonin production and the human circadian system', Prog. neuro-psychol. biol. Psychiat., 1983, 7: 551-556; A. Lewy, H. Kern, N. Rosenthal, and T. Wehr, 'Bright artificial light treatment of a manic-depressive patient with a seasonal mood cycle', Amer. J. Psychiat., 1982. 139: 1496-1498.

${ }_{13}$ Zhitie $i$ tvoreniia, op. cit., note 9 above, p. 49; Fedotov, op. cit., note 9 above, pp. 117-119.

14 Thus all the nuns in a convent were penalized (denied communion for seven years!) for having failed to "calm down" and "reconcile" two nuns who had become depressed and committed suicide. The first had drowned herself after being reproached by the second for conversing with a lay tailor outside the convent: the second had hanged herself when she realized she had been responsible for the death of the first: Khristianskaia zhizn' po dobrotoliubiiu, op. cit., note 7 above, p. 74.

${ }^{15}$ Riazanovskii, op. cit., note 2 above, pp. 88-89.

16 Stoglav, 2nd ed., Kazan', 1887, ch. 52, pp. 117-121, and ch. 5, question 22, p. 33.
} 


\section{Some perceptions of mental disorder in pre-Petrine Russia}

Here, saints effected miraculous cures. One Iurii Kazarinov had drunk so much that he became quite mad. Taken to the grave of St Adrian Poshekhonskii (late sixteenth century), Iurii was healed. He later suffered a relapse, but was cured again, presumably permanently. ${ }^{17}$ Another man who had "become addicted to excessive drinking" finally lost his mind, raging and shouting nonsense. He was restored to health through the intercession of St Pakhomii Nerekhetskii (d. 1384). ${ }^{18}$

A third category includes a wide range of cases involving irrational, often violent behaviour. All were attributed to the devil or evil spirits. One procedure for driving out evil spirits was to bring the sufferer to the tomb or church of a saint, or to a living clergyman for treatment. In either case there would be prayers; sometimes the demon was commanded in God's name to leave the victim, who would be blessed with holy water or anointed with oil and perhaps ordered to fast or follow other prescribed steps. Pre-Petrine sources include many accounts of such therapy. Unfortunately, they are usually so laconic that we cannot identify the type of "madness" involved. Since these afflictions were brought on by the devil, there was apparently little point in giving them distinct labels; the objective was to cure them by driving away the unclean spirits which had caused them in the first place. Let us consider some case histories.

Zinovii, a resident of Beloozero, become so mentally disturbed that onlookers were horrified when they saw him. He was brought to a monastery where St Sergii Nuromskii (d. 1421) lay buried. A prayer service for Zinovii's recovery was begun. While the service was going on, a large oven was lit in the monasterial dining hall. Suddenly the madman (besnovatyi) struggled free from the persons holding him and flung himself into the flaming oven. Those present barely managed to pull him out; they took him to another room, where Zinovii kept seeing "many demons". Then he had a vision of an "elder" (starets) walking towards him and holding an icon of the Immaculate Mother of God. The elder identified himself as Sergii; it was the saint, Sergii Nuromskii, through whose prayers Zinovii recovered. ${ }^{19}$

This was a classic case of "intercession" rather than "exorcism". Whether Zinovii behaved pathologically at the demons' hands or recovered after the saint's prayers, most Russians were convinced that Zinovii had actually seen both the demons and the saint. His vision of Sergii, in particular, was considered no hallucination; it was a true Vision, a supernatural event. Kroll and Bachrach have recently shown that a similar outlook prevailed in medieval Europe. If contemporary research ascribes "visionary experiences" to such "contexts" as malnutrition (fasting, starvation), stressful situations, toxic states, metabolic derangements, illnesses, delirium, psychoses, ${ }^{20}$ and so on, medieval Western Europe usually accepted the experiences as bona fide visions. Kroll and Bachrach limited their research to data from England, France, and Minnesota, yet their assertion that "the medieval description of insanity does not seem to include hallucinations" 21 applies equally well to Russia. From eleventh-century

${ }^{17}$ Zhitiia sviatykh na russkom iazyke, Aprel' Moscow, 1906, p. 400 (hereinafter Zhitiia sviatykh).

18 Ibid., p. 469.

19 Zhitiia sviatykh, Oktiabr', Moscow, 1904, p. 145.

$20 \mathrm{~J}$. Kroll, and B. Bachrach, 'Visions and psychopathology in the middle ages', J. nerv. ment. Dis., 1982, 170: 42, 44-45.

${ }_{21}$ J. Kroll and B. Bachrach, 'Medieval visions and contemporary hallucinations', Psychol. Med., 1982, 12: 714. 
Kiev to seventeenth-century Moscow, Russians recorded such "visions" and drew appropriate conclusions from them. ${ }^{22}$

As noted earlier, laconic descriptions of symptoms often render "diagnosis" difficult if not impossible. We read that a certain Simeon "had the misfortune of being mentally confused; devils appeared to him and subjected him to indescribable terror." Modern readers might hypothesize that Simeon was suffering from "hallucinations" or "anxiety neurosis", but the original account states that Simeon was healed through the intercession of St Evdotii Suzdal'skii (d. 1404). ${ }^{23}$ The same saint rescued the boyar Dmitrii, who had suddenly "gone mad"; recognizing none of his relatives, and being unable to find the way home by himself. He saw apparitions and would fly into periodic frenzies. Did all this mean that the boyar had fallen into a psychotic state which later went into remission? Whatever the problem, he was reported healed through St Evdotii's help. ${ }^{24} \mathrm{~A}$ visit to the grave of St Daniil Pereiaslavskii brought relief to a man who had been beating the wall with his hands, rolling his eyes wildly and driving away those who were close to him. Violently deranged persons were brought to the grave of Alexander Nevsky (c.1220-63) centuries after the death of that hero-saint; the victims' symptoms reportedly disappeared. ${ }^{25}$

Among the tombs frequently visited in the hope of recovery from mental illness were those of saints who had been iurodivye or "holy fools". Many of these "fools in Christ" had themselves displayed what modern readers would consider symptoms of mental disorder, as we shall see below. Two of Russia's most revered iurodivye were Prokopii of Ustiug (d. 1303?) and Moscow's Vasilii Blazhennyi ("Basil the Blessed", d. 1552?). Half-a-dozen "madmen" were reported cured on various occasions at Prokopii's tomb. Their recoveries followed prayer services during which they had kissed the saint's icon or prostrated themselves before the coffin. Virtually no details are given about the "madness" that afflicted these men; we are told merely that one of them was "confused in mind" and "uttered senseless words", while another had to be "bound with ropes" before being brought to the church. ${ }^{26}$

Two "madwomen" were healed after visiting Vasilii's tomb. Of the first, Evfimiia, we learn only that she "had been possessed by an unclean spirit for thirty-five years". She dreamed of the saint, who told her to come to his tomb in Moscow. She went, and found there a multitude of people seeking "spiritual and bodily healing" at the church. Her own symptoms disappeared. ${ }^{27} \mathrm{~A}$ few more details are supplied in the case of the madwoman Kseniia, who had been "drinking something" before a holiday meal when suddenly she "was struck dumb and lost her mind". Because she raved and ranted and

\footnotetext{
${ }^{22}$ The Kiev Cave Patericon teems with demonclogy but also reports visions of brilliant lights in the sky, a levitating monastery structure, etc. One of the monks, Isaac the Cave-dweller, suffered a breakdown after a visit by demons who jeered him, danced, and played musical instruments; see old Russian texts in D. Tschižewskij (editor), Das Paterikon des Kiever Höhlenklosters, Munich, 1964, pp. 185-189. A seventeenthcentury heroine, Julianiia Osor'ina, was surrounded by demons "who wished to murder her", but was saved by the miraculous appearance of Saint Nicholas, who "dispersed them". M. Skripil" (editor), Russkaia povest' XVII veka, Moscow, 1954, p. 44. (This work was a biography by Julianiia's son!)

${ }^{23}$ Zhitiia sviatykh, Aprel, p. 500 .

${ }^{24}$ Ibid., p. 502.

${ }^{25}$ Ibid., p. 557; and Zhitiia sviatykh, Avgust, Moscow, 1911, pp. 567-568.

26 V. Shliapin (compiler), Zhitie pravednago Prokopiia ustiuzhskago chudotvortsa, St Petersburg, 1903. pp. 46, 49, 50-51.

${ }_{27}$ I. Kovalevskii, Iurodstvo o Khriste i Khrista radi iurodivye v russkoi tserkvi, Moscow, 1895, p. 231.
} 
tried to tear off her clothes, it became necessary to restrain her with ropes. Some relatives recalled Vasilii Blazhennyi's many miracles and took Kseniia to his tomb. There a prayer service was conducted for the "madwoman" (besnovataia) and she was blessed with holy water. She promptly recovered. ${ }^{28}$

Other holy fools who reportedly restored mental patients to a normal state by posthumous miracles included Isidore of Rostov (mid-fifteenth century), Lavrentii of Kaluga (late fifteenth and early sixteenth centuries), and Prokopii of Viatka (d. 1627). Almost two centuries after Isidore's death, a man was brought to his tomb for a cure. The man had drunk excessively and been stricken with "white fever"; the pupils of his eyes were dilated and the eyes had an "unusual glitter". Possessed of "extraordinary physical strength", the man went around "beating everyone up". He was brought in fetters to Isidore's tomb, where he screamed and babbled "like a madman". When a kanon was sung to the saint, the man regained his senses. Complete recovery followed. ${ }^{29} \mathrm{St}$ Lavrentii is credited with no less remarkable assistance. In 1622, Stefan, a young inhabitant of Kaluga who was "mad" (besnovatyi), was brought by his parents to the monastery where the holy fool had been buried two centuries earlier. During prayers to the saint, Stefan began to resist his parents wildly; he was "terrified by evil spirits appearing as wild beasts who wished to tear him apart". Then Saint Lavrentii appeared before Stefan and drove away the demons. Stefan fully regained his sanity after a prayer service. ${ }^{30}$ In 1666 , Marfa Timofeevna, a young woman who was "possessed by evil spirits" (no further details are given), recovered after a vision of two saints, one of them the holy fool Prokopii of Viatka. ${ }^{31}$

Such accounts of miraculous cures will surely find sceptics today. Yet let us consider just what happened at a prayer service or moleben (Te Deum in Latin) ${ }^{32}$ for a victim of mental disorder. Quite apart from their specific prayers and readings, such services could have a therapeutic effect on patients. Just hours earlier, the patient had been alone and neglected (or, in some cases, mocked and abused). Now, transferred to the church, he found himself the centre of care and the object of prayer. The service was held in the middle of the church; the public was welcome; parishioners came and went, sometimes with their children and elderly parents; they could stand where they pleased. The service began when the priest came, accompanied by a deacon and altar boy. The afflicted person was blessed with the cross and with holy water; he kissed the icon of the saint and heard the priest invoke that saint's help in healing the patient. Perhaps he was also anointed with oil. (During that sacrament there were special readings and songs. Oil was blessed, then dabbed on the patient's face at four points, in the sign of the cross.) All the while, family members, friends, and other parishioners crowded around the patient, who now felt that many worshippers were concerned about his suffering; he must have felt himself part of a larger group of believers in touch with the saint and, through the saint, with God Himself. That such proceedings, in such a setting, could have offered therapeutic benefits to many patients seems beyond question. ${ }^{33}$

28 Ibid., p. 232.

29 Ibid., p. 246.

30 Ibid., p. 253.

31 Ibid., p. 258.

32 D. Sokolof (compiler), A manual of the Orthodox church's divine services, New York, 1899, pp. $145-147$. 


\section{H. W. Dewey}

If some people were delivered from madness by services and posthumous miracles of saints, others were reported healed by living clergymen. Our most detailed and revealing information on this brand of therapy comes from the autobiographical vita of Archpriest Avvakum, written in the second half of the seventeenth century. Most of the accounts appear at the end of the work (where posthumous miracles are often reported in conventional vitae), but the events described had occured at various times throughout the author's life.

Avvakum's accounts have the advantage of being more detailed than most. Initially, however, he appears to promise us more reports of instant, miraculous cures. For example, he tells us that several "lunatics" (beshannykh) were brought into his home over the years, and "after the prayers of the Holy Fathers, the devils departed from them by the command and action of the living God and of our Lord Jesus Christ, the son of God our Light." After Avvakum had blessed the patients "with tears and holy water" and had anointed them with oil, "chanting supplications in Christ's name, the power of God cast out the devils from these men and they were made whole." 34 This might lead us to expect that all "lunatics" recovered promptly and completely when treated in such a way. Nothing could be further from the truth, as Avvakum's subsequent accounts make clear.

We must remind ourselves that Archpriest Avvakum was a traditionalist who insisted on observing time-honoured rituals and formalities. His opposition to innovation, especially in the area of church reform, is well known. Hence we have reason to believe that he was following well-established procedures when he sought to help mental patients.

The first of the archpriest's more detailed accounts concerns Maria and Sofia, a couple of "madwomen" who had been house-servants of Afanasii Pashkov, the military commander in Siberia. Both women were widows and "possessed of an unclean spirit". At first, their master had tried to have them cured with old folk remedies - charms and conjurations (incantations), but the women continued to "beat themselves and scream". (Were they perhaps a pair of klikushi-women afflicted with a "nervous disorder" which causes "hysterical seizures", screams, and convulsions?) 35 Finally, Pashkov brought both women to Avvakum in the hope that he could make them whole. Avvakum fasted-and made the women fast as well. He then "made supplication, anointed the women with oil ... confessed them and gave them the sacrament", after which "they became whole in body and mind". The matter did not rest there, however. The women became Avvakum's "spiritual daughters" and wished

\footnotetext{
${ }^{33}$ Park and Shapiro (op. cit., note 6 above, pp. 9, 19) report that some patients respond well to the attention of volunteers and various types of social interaction. See Timothy Ware's remarks on the "flexibility" and "unselfconscious informality" of the Russian church, with worship a "family affair", The Orthodox Church, New York, 1963, pp. 275-276. For the curative effects (in some cases) of autosuggestion and faith, see T. Graham, Medieval minds. Mental health in the middle ages, London, Allen \& Unwin, 1976. p. 35 .

${ }^{34}$ N. Gudzii (editor), Zhitie protopopa Avvakuma, im samim napisannoe, Leningrad, 1960, p. 76. An excellent English translation may be found in K. Brostrom (translator and editor), Archpriest Avvakum. The life written by himself, Ann Arbor, University of Michigan Press 1979, pp. 65-66.

35 Slovar' russkogo iazyka in 4 vols., vol. 2, Moscow, 1958, p. 73. For a discussion of klikushi in nineteenth-century Russia see G. Popov, Russkaia narodnobytovaia meditsina (po materialam etnograficheskago biuro kniazia V. N. Tenisheva, St Petersburg, 1903, pp. 396, 976.
} 


\section{Some perceptions of mental disorder in pre-Petrine Russia}

to stay with him, but Pashkov came and took them back. They promptly suffered a relapse, starting to "rave even worse than before". Only after Avvakum had secretly sent them some holy water and anointed them once again with oil did they "become whole". 36

Another remarkable episode describes the seizures of Avvakum's teenage brother Evfimei, who was stricken while reading from a liturgical text. Evfimei suddenly fell to the ground, "smitten by devils". He started to cry out and scream in terrible "voices" and thrashed about with such violence that several men could barely restrain him. The archpriest read prayers of Basil the Great over the "frenzied lad" while other persons held him down. A full-fledged "exorcism" followed: the devil was commanded in the name of the Lord to leave Evfimei; Avvakum censed icons; he censed his "possessed" brother; he wept; he again prayed and ordered the devil to come out of Evfimei; he blessed Evfimei with holy water. The devil came out, but had to be dislodged from various refuges nearby; Evfimei would point to the place where he saw the devil cowering (window-ledge, millstone, stove) and Avvakum would sprinkle the area with holy water. Avvakum had to leave for church. When he returned, "the devils [sic] had reentered Evfimei", but left when the archpriest anointed his brother with oil. Several weeks passed before Evfimei, "broken in body by the devils", finally recovered. ${ }^{37}$

Avvakum describes a "lunatic", Kirilushko the harquebusier, who was at once Avvakum's prison guard and his patient. Kirilushko's symptoms-ravings, incontinence, drivelling, refusal to eat-resemble those caused by a degenerative brain disease, but Avvakum saw him as possessed: "the devil made him do foul things to vex me". The archpriest prayed over him and anointed him with oil, "and this eased him from the devil". When Kirilushko lay dying, Avvakum confessed him and gave him the sacraments. He also insisted on a proper church burial and requiem for his erstwhile jailer. $^{38}$

Filipp was a "lunatic" living in Avvakum's house in Moscow. Because the devil in Filipp was "uncommonly harsh and savage", Filipp had to be kept chained in a corner of the archpriest's residence. Avvakum's busy schedule kept him away during the daytime; only at night was he able to "minister unto Filipp", coming to him "with the Cross and holy water". Such measures usually kept Filipp passive and subdued, but once Avvakum returned home to find his wife and her maid in a loud argument. The archpriest "beat them both, offending them grievously". Then "the devil in Filipp began to rage"; in a frenzy, Filipp broke his chains and attacked Avvakum. The archpriest realized that God was punishing him, through Filipp, for having mistreated his wife and the maid. Instead of trying to heal his attacker, Avvakum submitted to Filipp's blows. He did further penance by begging forgiveness from the women he had beaten and ordering all present to lash him across the back, "five blows each". Only then did the devil leave Filipp, who "became good tempered as before". 39

Yet another "lunatic"-Fedor-resided at Avvakum's house. The archpriest was convinced that Fedor's mental condition had resulted from the sin of having had

${ }^{36}$ Gudzii, op. cit., note 34 above, pp. 76-77; Brostrom, op. cit., note 34 above, pp. $66-67$.

${ }^{37}$ Gudzii, op. cit., note 34 above, pp. 111-113; Brostrom, op. cit., note 34 above, pp. 102-104.

${ }^{38}$ Gudzii, op. cit., note 34 above, pp. 113-114; Brostrom, op. cit., note 34 above, pp. $104-105$.

${ }^{39}$ Gudzii, op. cit., note 34 above, pp. 114-115; Brostrom, op. cit., 34 above, pp. 105-106. 
sexual intercourse with his wife at Easter, "heaping curses on the festival all the while". Fedor had been delivered to Avvakum in a "frenzy"; the archpriest treated him for a good two months. Fedor responded well at first; Avvakum had led him to church, prayed for him, and anointed him with oil. When Fedor began chanting from the choir during the liturgy, however, Avvakum lost patience, beat him, and "ordered the sexton to chain him to the narthex". Fedor thereupon suffered a relapse; he became violent again, tore himself loose, and ran away. He later recovered his sanity, reporting that Avvakum had appeared to him in a vision, blessed him with the cross, and driven his devils away. ${ }^{40}$

Among Avvakum's other patients was a young widow named Afimiia, who had suffered a seizure and lay in the middle of the room "as if dead". Even after regaining consciousness, Afimiia's arms and legs remained "stiff and stonelike". The archpriest stroked her with the cross and she recovered partly, but she was not "made whole" until he anointed her with oil. ${ }^{41}$ Another young woman, Anna, had been Avvakum's maid. She had apparently been seduced by her first master, Elizar. When she decided to leave Avvakum and go back to Elizar, "the Lord set a devil upon her and humbled her, for she no longer heeded me in anything ... ". She would come to church, only to "fall into a frenzy". Avvakum's efforts to relieve her by blessing her with a cross and holy water brought only temporary relief. While the archpriest was in exile, Anna married Elizar and had two children, then took the veil for undisclosed reasons. After Avvakum's return from exile, Anna entered the church behind him, but the devil fell upon her during the Mass: "she started shouting and crying out, barking like a dog, bleating like a goat and cuckooing like a cuckoo." Only after an exorcism did Anna recover. $^{42}$

Avvakum's testimony is valuable because it makes-or reinforces-several points. Not even a dedicated clergyman believed that mental disorders could always be "cleared up" promptly and miraculously by prescribed religious rituals. There were occasions when the archpriest could not even report a partial or temporary cure. A couple of "lunatics", both named Vasilii, lived chained in his house for some time. They "ate their own excrement" and could not be "made whole". 43 Perhaps these unfortunate men were severely retarded individuals. Others, more intelligent, could not be healed because they lacked faith. ${ }^{44}$ Still others managed to be cured, but only after an arduous struggle with discouraging setbacks. The devil did not give up easily.

Avvakum was a fundamentalist, yet most Russians doubtless shared his conviction that spectacular cases of possession could only be cured by miraculous intercession or

\footnotetext{
40 Gudzii, op. cit., note 34 above, pp. 115-116; Brostrom, op. cit., note 34 above, pp. 106-107.

${ }^{41}$ Gudzii, op. cit., note 34 above, pp. 116-117; Brostrom, op. cit., note 34 above, p. 108.

42 Gudzii, op. cit., note 34 above, p. 118; Brostrom, op. cit., note 34 above, pp. 108-110. The symptoms here resemble those of lycanthropy - "a type of melancholia"; Jackson, op. cit., note 6 above, pp. 282, 290. Another spectacularly afflicted woman was Solomoniia the Possessed (besnovataia), who was repeatedly raped by the devil and demons, bearing their offspring before exorcism. Solomoniia's ordeal was attributed to her improper baptism by a drunken priest; her story appears in G. Kushelev-Bezborodko (compiler), Pamiatniki starinnoi russkoi literatury, 2 vols., vol. 1, St Petersburg, 1860, pp. 153-168.

${ }^{43}$ Gudzii, op. cit., note 34 above, p. 117; Brostrom, op. cit., note 34 above, p. 108.

44 That the victim had to have faith is clear; Gudzii, op. cit., note 34 above, p. 76; Brostrom, op. cit., note 34 above, p. 66.
} 


\section{Some perceptions of mental disorder in pre-Petrine Russia}

exorcism. In other instances, however, one must wonder whether the devil and his demons were really blamed.

A case in point would be blud (lust, fornication, illicit sexual conduct). Like depression, blud was devil-inspired-one of the eight great sins or vices. Nil Sorskii had enjoined his fellow monks to "avoid all conversation with women, and indeed the very sight of them; shun youthful, beardless and effeminate faces, for the devil lays these snares for monks." ${ }^{45}$ Russian literature offered examples of persons who, under the devil's control, engaged in licentious sexual behaviour and occasionally went on to commit crimes like murder. ${ }^{46}$ One hero displayed the symptoms of classic "lovesickness" while in the throes of an illicit affair. ${ }^{47}$

Yet the association of blud with madness seems tenuous. If its victims were "possessed" in a manner calling for exorcism or intercession, they supposedly fell into that condition after the act, and as a penalty for their transgressions, rather than committing the offence because of their "seizure". A fifteenth-century manuscript tells of a woman who became possessed for going to church after having intercourse with her husband; ${ }^{48}$ Avvakum's patient, Fedor, went mad after having sexual relations with his wife at Easter. ${ }^{49}$ And on one occasion, the Patriarch himself-whom we would assume to have been well versed in such questions-dispensed with the notion of demonic possession altogether. In 1628, this Patriarch learned that N.Semichov, a member of the gentry, had had sexual relations with female slaves and that the women had borne him seven children. Such blud might well have been blamed on the devil and made Semichov a candidate for a ritual exorcism. The Patriarch took a less "spiritual" course: he had Semichov arrested and taken in chains to a monastery. There Semichov was put on a restricted diet and made to perform exhausting tasks. He was denied the right to any sacraments unless near death, and guards watched over him constantly to prevent him from committing suicide. ${ }^{50}$ Moral offences such as Semichov's had been punishable under canon law ever since Russia had embraced Christianity. Blud may have constituted irrational behaviour, instigated by the devil, but it was not the sort of "possession" (in the absence of a fit or seizure) which called for intercession or exorcism.

The church remained convinced that only that therapy which was administered by clergymen had any value for mental patients. Non-clerical folk healers seem to have enjoyed a considerable following, but the church viewed them as charlatans. In the above-described case of the two "screaming women", Pashkov had first called upon folk healers; only after their charms and incantations had proved to no avail did Pashkov turn to Avvakum for help. The woman described above who became possessed after her sexual misconduct ${ }^{48}$ was first brought to folk healers for treatment. Their charms and incantations only made things worse; she became wracked with convulsions. Finally, she was brought to a Christian clergyman named Fotronot, who

\footnotetext{
45 Fedotov, op. cit., note 9 above, p. 144.

${ }^{46}$ See text of 'Tale of Moscow's founding', in M. Salmina, Povesti o nachale Moskvy, Moscow, 1964, pp. 200-201, 206-208.

${ }^{47}$ See text of 'Tale of Savva Grudtsyn', in M. Skripil', Russkaia povest', pp. 87, 89; Jackson, op. cit., note 6 above, pp. 290-291.

48 Pamiatniki starinnoi russkoi literatury, p. 210.

49 See note 40 above.

50 Akty arkheograficheskoi ekspeditsii, 4 vols., vol. 3, St Petersburg, 1856, no. 117, p. 259.
} 


\section{H. W. Dewey}

managed with great difficulty to drive the devils out of her. Her story ends with a double warning: not to go to church after having sexual relations, and not to put one's trust in pagan sorcery (volkhvovanie) to exorcise devils.

On another occasion, a youth named Grigorii lost his mind and became so disorderly that he had to be shackled. Freeing himself, he ran away, ripping off his clothes and throwing them about. Grigorii was recaptured and confined to a room, but continued to wreak havoc. "Many wizards" (volkhvy) were summoned to treat him, but their efforts proved fruitless, for "who could help but God?" Brought to the monastery where St Alexander Oshevenskii lay buried, Grigorii was cured after a special prayer service. ${ }^{51}$

The church's opposition to folk healers may also explain the absence (in surviving sources) of references to drugs, herbal remedies, or special types of food in treating the mentally ill, despite the fact that Russia had an abundance of herbal remedies for other ailments. ${ }^{52}$ In our own time, many still believe that certain herbs and spices relieve mental conditions ranging from anxiety, nervous tension, depression, apathy, to paranoia, hypochondria, panic, and hysteria, ${ }^{53}$ but Russian churchmen apparently rejected such "internal medication" in favour of spiritual remedies. For all this, many Russians continued to put their trust in folk healers; the "incantation" (zagovor or zaklinanie) remained the most popular of the magical cures. ${ }^{54}$ Some incantations were directed against melancholy or depression, others against "fits" or "paroxysms", still others against alcoholism and "fright" (perepolukha). ${ }^{55}$

We turn now to another set of perceptions: those which underlay the reluctance to recognize mental disorder in cases where modern psychiatrists would almost certainly spot it.

One of the most famous Russians to suffer from mental problems was Tsar Ivan IV ("the Terrible", 1530-84). His problems manifested themselves at an early age. As a twelve-year-old, Ivan enjoyed killing dogs and cats by hurling them down from lofty places: at fifteen, he and "selected companions" would ride on horseback through the town squares and marketplaces, "beating and robbing the common people, men and women"; by seventeen-long before his reign of terror in the oprichnina-he had become fond of executing nobles and great landholders. Only the great fire and riots of 1547 temporarily checked his savage conduct. ${ }^{56}$ Still later, especially from 1564 to 1571 , Ivan's behaviour became pathological by virtually any yardstick. He seems clearly to have suffered, among other things, from severe paranoia. ${ }^{57}$

\footnotetext{
51 Zhitiia sviatykh, Ianvar'-Aprel', Moscow, 1916, pp. 630-631.

52 M. Rowell, 'Russian medical botany before the time of Peter the Great', Sudhoffs Archiv, 1978, 62: 339-358.

${ }^{53}$ An example: M. Shaw, 'New from herb and spice: fragrances and essential oils', People's Food Co-op Connection, March-April, 1985, p. 5 (citing R. Tisserand's The art of aromatherapy). For lay physicians' use of herbal remedies in the West, see Jackson, op. cit., note 6 above, p. 295.

54 R. Zguta, 'Witchcraft and medicine in pre-Petrine Russia', Russian Revien', 1978, 37 : 443.

55 Z. Vlasova, 'K izucheniiu poetiki ustnykh zagovorov', Russkii fol'klor, 1972, 13: 194-201; V. Il'inskaia, 'Zagovory i istoricheskaia deistvitel'nost', ibid., 1976, 16: 200-207. See texts of zagovory in Popov, op. cit., note 35 above, pp. 224-249.

56 J. Fennell (editor and translator), Kurbsky's history of Ivan IV, Cambridge University Press, 1965. pp. $10-11$.

${ }^{57}$ See, for example, R. Hellie, 'Ivan's paranoid delusional system', Russian History [forthcoming].
} 


\section{Some perceptions of mental disorder in pre-Petrine Russia}

Prince Andrei Kurbskii did not hesitate to call Ivan "mad" (bezumnyi) and a tool of the devil. ${ }^{58}$ But Kurbskii was writing from abroad, in the safety of self-imposed exile. Muscovites who stayed at home saw Ivan's conduct quite differently, and made no claims that he was out of his mind, Madness was equated with possession by the devil, while the Muscovite establishment viewed the tsar as God-crowned, guarded by God, God's representative on earth, and so on. ${ }^{59}$ To ascribe Tsar Ivan's atrocities to madness, i.e. possession by the devil, would have been an anomaly, unacceptable as an explanation of Ivan's crimes against his people. Even when they recognized the tsar's cruelty, loyal Russians attributed it to the "multiplication of sins among all Orthodox Christians"; i.e., God was punishing them for their sins. Later, claimed one chronicler, God grew angry with Ivan and took mercy on His people, granting them a period of wellbeing and "gentle tranquility" (under Ivan's successor, Feodor I (1584-98)). ${ }^{60}$

Russia's holy fools or "fools in Christ" (iurodivye) have been labelled "local madmen" by a Soviet researcher. ${ }^{61}$ One must recognize that the conduct of holy fools frequently resembled that of persons suffering from some mental disorder. They made "irrational" utterances and performed "irrational" acts. Some may indeed have been autistic: one thinks of Mikhail Klopskii's echolalia and Prokopii Ustiuzhskii's ritualistic gestures with pokers. Several traits ascribed to Vasilii Blazhennyi (Basil the Blessed), Moscow's celebrated holy fool, were shared by other iurodivye and coincided with behaviour commonly observed in autistic individuals: social immaturity or "impairment", speech problems (some accounts insist that Vasilii hardly spoke at all), unusual posture or gait (Vasilii walked with his head facing upwards, eyes raised to the sky), insensitivity to extremes of cold and heat (Vasilii was known as a nagokhodets, one who walks naked, even in wintry weather, and is so depicted in some icons) and a tendency to smile or laugh for no apparent reason. Holy fools often gave unusual, highly original interpretations of what they saw or heard. Loners and helpless individuals, they were often ridiculed or abused by onlookers. ${ }^{62}$

Nonetheless, the prevailing (church-sanctioned) view was that holy fools were perfectly sane individuals. They were merely pretending to be mad. They feigned madness in order to act on St Paul's dictum that divine folly surpasses man's wisdom and that divine weakness is superior to man's strength. To shame the wise and powerful, God has chosen those whom the world regards as foolish and weak (I Cor. 3:18-21). Some biographers took pains to provide a "rational" interpretation for their

${ }^{58}$ Fennell, op. cit., note 56 above, pp. 162-167, 286-289.

${ }^{59}$ See, for example, M. Cherniavsky, Tsar and people, New Haven, Conn., Yale University Press, 1961, pp. 44-71 and passim. The established church had emphasized and elaborated such notions since the time of Joseph of Volokolamsk; M. Raeff, 'An early theorist of absolutism: Joseph of Volokolamsk', American Slavic and East European Review, 1949, 8: 181.

60 I. M. Katyrev-Rostovskii, 'Povest' ot prezhnikh let', in A. Stender-Petersen (editor), Anthology of Old Russian literature, New York, Columbia University Press, 1954, pp. 327-328. It is true that certain "unofficial" legends of popular nature (especially from Novgorod and Pskov) denounced Ivan for his cruelties; e.g. V. Sokolova, Russkie istoricheskie predaniia, Moscow, 1970, p. 61.

${ }^{61}$ I. U. Budovnits, 'Iurodivye drevnei Rusi', in Voprosy istorii religii $i$ ateizma, Moscow, 1964, pp. $178-180,183$.

${ }^{62}$ For contemporary studies of autistic behaviour, see, inter alia, L. Wing, 'Epidemiology of early childhood psychoses', Handbook of psychiatry 3: Psychoses of uncertain aetiology, Cambridge University Press, 1982, pp. 212-214; and U. Frith, 'Psychological abnormalities in early childhood psychoses', ibid., pp. 215-221. We have discussed holy fools (and sources pertaining to them) in several articles, including $N$. Challis and H. Dewey, 'The blessed fools of Old Russia', Jahrb. Ges. Osteuropas, 1974, 22: 1-11. 


\section{H. W. Dewey}

heroes' seemingly senseless conduct: Vasilii threw stones at a house in which God-fearing people were praying because he could see the unclean spirits which had fled that righteous abode: Vasilii was stoning the departing demons, not the dwelling itself. $^{63}$

In my opinion many iurodivye may indeed have been mentally "handicapped" in real life, the prevailing view notwithstanding. There are hints of this, possibly unintentional revelations by the monks who collected and wrote down material on holy fools. ${ }^{64}$ But no matter. The fact remains that divine folly was generally perceived as a deliberately chosen way of life, rather than as a manifestation of mental disorder. Mental illness signified possession by the devil. The iurodivye, by contrast, served God and fought the devil, unmasking evil and trying to save souls. Muscovites regarded their handicapped Tsar Feodor (son of Ivan IV) as a holy fool. A partial explanation for the surprising military achievements, eastward territorial expansion, and other successes which marked his reign may be found in the mood which united the nation: "The Russians believe that holy fools are under God's special protection . ... The presence of such a 'fool' on the throne of Russia brought comfort and consolation to the nation deeply stricken by the terror of Ivan's reign . . .. God would show His mercy to a nation which obeyed its helpless sovereign."65 In no other nation-particularly by the fifteenth and sixteenth centuries- was divine folly so revered as in Muscovite Russia. Some three dozen iurodivye actually became saints in the Russian church.

Such views continued to influence life in the Russian countryside until the twentieth century. There the harmless mentally ill (tikhie pomeshannye) were viewed "with love and compassion" by most of the peasantry. Addressed by the affectionate diminutive (Ivanushka, Mariiushka), they could wander about as they pleased. They were fed, sheltered, and included in various festivities. Many peasants regarded them as holy fools with powers of clairvoyance, and were happy to give them odd jobs (sweeping, looking after livestock, fetching water). Of course, there were others, less sympathetic, who mocked the "fools", played tricks on them, and even subjected them to physical abuse. ${ }^{66}$

As if to compensate for the view of iurodivye as sane men, Russians sometimes professed to discern madness in conduct which present-day observers would find quite

${ }^{63}$ I. Kuznetsov, 'Sviatye blazhennye Vasilii i Ioann, Khrista radi Moskovskie chudotvortsy', Zapiski Moskovskago arkheologicheskago instituta, Moscow, 1910, 8: 85. For Vasilii's posthumous miracles in healing the mentally ill, see pp. 64-65, 67, 69-70. For sources' insistence that divine folly was feigned "by [the fools'] own volition", see pp. 341-343. Insightful comments on the "paradoxical" behaviour of certain holy fools (including Vasilii) may be found D. Likhachev and A. Panchenko, "Smekhovoi mir" drevnei Rusi, Leningrad, 1976, p. 131.

64 Prince Konstantin, after identifying the strange newcomer in the monastery, requests the abbot to take special care of Mikhail, the prince's relative; $\mathbf{N}$. Challis and $\mathbf{H}$. Dewey, 'Disparate images of Mikhail Klopskii'. Slavic Review, 1983, 42: 654. The youthful holy fool, Ioann Ustiuzhskii, was generally regarded as "mentally handicapped" (ne v polnom ume) and his mother felt obliged to keep him constantly with her, even after she entered a convent; Zhitiia sviatykh. Mai, Moscow, 1908, pp. 758-759.

${ }^{65}$ N. Zernov, The Russians and their church, London, SPCK, 1964, pp. 68-69. Baldwin Hamey, an Englishman visiting Russia at the time, professed to see through Feodor's "apparent simplicity". Hamey perceived the tsar as a "cunning plotter behind the mask of the 'Fool of God'." J. Keevil, Hamey the stranger, London, Geoffrey Bles, 1952, p. 59. One can find interesting parallels between the popular views of Feodor in Russia and Henry VI in England; Clarke, op. cit., note 11 above, p. $196 \mathrm{ff}$.

${ }^{66}$ Popov, op. cit., note 35 above, pp. 364-366. 


\section{Some perceptions of mental disorder in pre-Petrine Russia}

normal. We speak of dissent_-political and religious dissent. A few examples merit our attention here.

Political dissent and active opposition to Moscow's rule reached a peak when many Russians switched allegiance to the so-called "False Dmitrii" in the Time of Troubles (1598-1613). Patriotic chroniclers blamed such conduct on the devil. The devil had put such thoughts in their minds; they had done something "mad" (bezumnyi). ${ }^{67}$

Madness could also be the punishment for opposing the rightful ruler, as we learn from the tendentious account of Sviatopolk the Damned's last days. Defeated by Yaroslav (the rightful ruler, in the chronicler's eyes), Sviatopolk fled, "and the evil spirit afflicted him; his bones became weak ... and he was carried on a stretcher to Brest." The evil spirit had driven Sviatopolk mad. He kept hallucinating, seeing Yaroslav's troops in pursuit whereas in fact "there was no one pursuing nor following his trail". As Sviatopolk drew nearer to Poland, he continued to cry out that "they are still pursuing me!" Finally, "in the wilderness between the lands of the Czechs and the Poles", Sviatopolk "lost his life cruelly". 68

Political opponents were not always labelled "insane"; far from it. And when they were so characterized, there may have been more than a little rhetoric involved. There was also a definite purpose to the charge: to discredit the opposition. The association of political dissent with madness had parallels in the area of religion. The dissidents held similar views of their foes. For an excellent example, we turn again to the writing of Avvakum. He described the fate of one of his former "spiritual children", the bathhouse employee Grigorii. Grigorii had defected to the opposition, so to speak, by going to a Nikonite priest for confession. Hardly had the priest given him communion when "the peasant [Grigorii] had a seizure and lost his mind". Avvakum later heard that "devils strangled Grigorii in the bathhouse". 69 The dissident archpriest had long hoped that Tsar Aleksei Mikhailovich would see the error of his ways and come back to the "true faith"- that espoused by the Old Believers. Eventually, Avvakum realized that the tsar had definitely sided with Avvakum's foes (the reformist faction headed by Patriarch Nikon). "Poor little insane tsar!", he exclaimed, presently lapsing into what would nowadays be regarded as obscenity: "Nu, skvoz' zemliu propadai, bliadin syn!" (roughly, "Well, drop dead, you son of a whore!"). ${ }^{70}$ After the tsar's death, Avvakum wrote to the monarch's son that Aleksei Mikhailovich was in hell ( $v$ mukakh on sidit) and blamed the late tsar's madness (bezumie) on the Antichrist and his agents, i.e., Nikon's faction. ${ }^{71}$

Lady Morozova, another Old Believer, likewise regarded Nikon's supporters as mentally affected and as agents of the devil. She, in turn, was denounced as a "daughter of the devil" by the frustrated Patriarch, who failed to bring her "to reason", i.e. to

\footnotetext{
${ }^{67}$ Katyrev-Rostovskii, 'Povest' ot prezhnikh let', p. 331; L. Cherepnin (editor), Skazanie Avraamiia Palitsina, Moscow-Leningrad, 1955, p. 8.

${ }^{68}$ See text in Stender-Petersen, op. cit., note 60 above, p. 90.

69 Text in Gudzii, op. cit., note 34 above, pp. 261-262.

70 Ibid., p. 229. A century and a half before the schism, Joseph of Volokolamsk had repeatedly linked a sect of religious dissenters (later known as the "Judaizers") to the devil: A. Zimin and Ia. Lurie (editors), Poslaniia Iosifa Volotskogo, Moscow-Leningrad, 1959, pp. 162, 169-171, 231.

${ }^{71}$ Gudzii, op. cit., note 34 above, p. 206.
} 


\section{H. W. Dewey}

bring her back to the fold of the official church. Lady Morozova's fellow sufferer, Princess Urusova, called the Patriarch "shameless and insane" to his face. 72

From such views of political and religious opponents as tools of the devil it was but a short step to the notion of witchcraft, i.e. of individuals who had "voluntarily entered into association with a devil". A witch differed from a demoniac, whose "possession" was involuntary. ${ }^{73}$ Much has been written about the trials and persecution of "witches" in Western Europe and the USA. As Walker has shown so convincingly, charges of witchcraft were frequently a tactic to discredit the opposition in the struggles between French Catholics and Huguenots, English Protestants and "Papists", Puritans and Anglicans. ${ }^{74}$

Perhaps it is because Russia enjoyed greater religious unity until the midseventeenth century, experiencing nothing on the scale of the religious wars which had raged in Europe, that her record is better here. Seventeenth-century Russia witnessed some witchcraft trials, it is true, but nothing to compare with what had gone on in the Catholic and Protestant West. ${ }^{75}$

\section{CONCLUSION}

When attempting to define perceptions of mental disorder in pre-Petrine Russia, one is constantly reminded that sources are limited in outlook as well as quantity. Surviving materials do suggest that views of demonic possession as the root of mental disorder prevailed in Russia to a greater extent than in the West. Both clergymen and their scorned colleagues, the folk healers, sought to cure their patients by driving out (or warding off) evil spirits. We find no references to natural aetiologies (e.g. physical illness, injury) alongside the supernatural, "spiritual" explanations for madness. Nor do we find references to drugs, herbal remedies, or special diets (except fasting) in the treatment of "spiritual" afflictions.

Surviving accounts generally describe patients with violently or flamboyantly irrational symptoms. Such victims were often brought by family members to a monastery or to a parish priest for treatment. We must assume that harmless patients generally lived at home; evidence from the Russian countryside in later centuries also suggests that the community at large tolerated (and helped) members who were deranged but harmless. Some of these unfortunates were regarded as "holy fools."

As for the efficacy of clerically-administered "therapy", three points are worth noting. First, we consider it likely that some patients really benefited from the rituals, or at least from the solicitude shown them during the service. Second, the clergymen

\footnotetext{
72 A. Mazunin (editor), Povest' o boiarine Morozovoi, Leningrad, 1979, pp. 130, 131, 136, 143-144, $148-149,155,159$.

${ }^{73}$ D. P. Walker, Unclean spirits. Possession and exorcism in France and England in the late sixteenth and early seventeenth centuries, London, Scolar Press, 1980, p. 10.

${ }^{74}$ Ibid., 28-29, 45-47, 56, 65-68 and passim.

${ }^{75}$ R. Zguta, 'Witchcraft trials in 17th-century Russia', Amer. Hist. Rev., 1977, 82: 1205-1207. The Russian church had been given jurisdiction over cases involving sorcery, magic, and witchcraft, and persons engaged in them were supposed to be punished, according to the church statutes of Vladimir and Yaroslav; see texts in V. Ianin (editor), Rossiiskoe zakonodatel'stvo $X-X X$ vekov, 10 vols., vol. 1, Moscow, 1984, pp. $120,149,191,203$, but no reports have survived of western-style campaigns against "witches." Cf. Graham, op. cit., note 33 above, pp. 77-80.
} 
made no claims that they could cure all mentally-deranged persons. Third, certain types of conduct which had been instigated by the devil (e.g., sexual offences) might be punished rather than "treated", suggesting that the offender was more to blame than the devil.

Of considerable interest are those types of behaviour which would today be considered evidence of mental disorder (e.g. "hallucinations"), but which were then regarded as sane, if supernatural ("visions"). Here the Russians not only shared a view held in Western Europe, but carried the process several steps further. We have in mind the phenomenon of divine folly (iurodstvo), which was far more widespread in Russia than elsewhere, and which the church insisted was a way of life deliberately assumed by ascetic men and women. Similarly, loyal subjects of Moscow did not accuse Ivan IV of madness,- -i.e. possession by the devil—because the Tsar ruled as God's representative on earth.

At the same time, Russians were quite capable of perceiving madness where we might see none. Russia apparently experienced nothing on the scale of the campaigns against "witches" in Western Europe, but pre-Petrine Russians were quick to characterize religious and political opponents as insane and as tools of the devil. This is a topic which merits further study. 